Hal: $37-46$

\title{
ANALISIS PELAKSANAAN PRAKTIKUM BIOLOGI KELAS VII DI SMP NEGERI SE- KECAMATAN MEDAN KOTA
}

\author{
SITI SUHARNI SIMAMORA \\ Program Studi Pendidikan Biologi, STKIP Labuhan Batu, Jalan SM Raja No 126 A, Aek Tapa, Rantauprapat
}

Diterima April 2018 dan Disetujui Juni 2018

\begin{abstract}
ABSTRAK
Pendidikan IPA menjadi suatu bidang ilmu yang memiliki tujuan agar setiap siswa terutama yang ada di SMP memiliki kepribadian yang baik dan dapat menerapkan sikap ilmiah serta dapat mengembangkan potensi yang ada di alam untuk dijadikan sebagai sumber ilmu dan dapat diterapkan dalam kehidupan sehari-hari. Pendidikan IPA atau IPA itu sendiri memiliki peran penting dalam meningkatkan mutu pendidikan terutama dalam menghasilkan peserta didik yang berkualitas yang mempunyai pemikiran kritis dan ilmiah dalam menanggapi isu di masyarakat. Salah satu metode pembelajaran IPA yang dapat menciptakan kondisi tercapainya hasil konsep keilmuan IPA dan komponen proses keilmuan IPA adalah dengan melaksanakan pembelajaran di laboratorium yang berupa praktikum. Pemanfaatan laboratorium atau kegiatan pratikum (biologi) merupakan salah satu metode pembelajaran yang dapat menumbuhkembangkan rasa ingin tahu siswa, aktif, kreatif, inovatif, dan kejujuran ilmiah dalam menghadapi suatu masalah dalam realita kehidupan, sehingga dapat menunjang pemahaman siswa terhadap materi pelajaran dan akhirnya tujuan pembelajaran akan tercapai sesuai yang diharapkan.
\end{abstract}

Kata Kunci : Sarana Pendidikan, Laboratorium, Praktikum Biologi

\section{Pendahuluan}

Sarana pendidikan adalah salah satu penunjang dalam meningkatkan mutu pendidikan. Terutama dalam pelaksanaan proses pembelajaran di sekolah sangat penting dalam mendukung kegiatan pembelajaran. Menurut Purnawan (2009:2) menyatakan bahwa peningkatan kualitas pendidikan di Indonesia selain bergantung kepada kualitas guru juga harus ditunjang dengan sarana dan prasarana pendidikan yang memadai.

Dalam pendidikan IPA, kegiatan laboratorium (praktikum) merupakan bagian integral dari kegiatan belajar mengajar. Hal ini menunjukkan betapa pentingnya peranan kegiatan laboratorium untuk mencapai tujuan pendidikan IPA (Rustaman, 2005:136-138) mengemukakan empat alasan pentingnya kegiatan praktikum IPA

Bahwa praktikum merupakan pusat pengajaran dan pembelajaran dalam ilmu dan kualitas kerja yang baik, praktikum membantu mengembangkan pemahaman siswa tentang konsep dan proses ilmiah.

$$
\text { Hasil penelitian Supriatna }
$$

(2008:50-52) terhadap 18 laboratorium sains SMA Negeri Binaan Pusat Pengembangan dan Pemberdayaan Pendidik dan Tenaga Kependidikan (P4TK) yang terbesar pada 7 provinsi di Indonesia antara lain ditemukan bahwa (1) hanya $33,33 \%$ dari SMA Negeri binaan yang memiliki sarana dan prasarana laboratorium yang memadai, (2) kualitas pengelolaan laboratorium masih tergolong rendah.

Setelah dilakukan survei, menunjukkan bahwa pemanfaatan laboratorium IPA Biologi belum maksimal, dan terlihat peralatan dan meja laboratorium berdebu, ini menunjukkan jarangnya ruangan laboratorium digunakan dan ruangannya kurang perawatan. Ruangan laboratorium IPA Biologi masih bergabung dengan laboratorium Fisika dan Kimia. 
Pelaksanaan praktikum masih jarang dilakukan ini disebabkan masih kurangnya sarana dan prasarana yang tersedia di laboratorium, jadwal praktikum tidak tersedia dan buku penuntun praktikum masih merupakan buku pegangan guru dan siswa saja, menyebabkan guru mengalami kesulitan dalam melaksanakan praktikum, kurangnya pengetahuan, keterampilan dan sumber daya guru dalam pelaksanaan pratikum juga pengaruh faktor umur dan pengalaman guru dalam mengajar.

Berbagai permasalahan pembelajaran biologi seperti masih terdapatnya guru biologi hanya mengajar dengan ceramah tanpa melibatkan siswa dalam proses pembelajaran. Tidak adanya penilaian terhadap hasil laporan praktikum Masih ada guru biologi yang kurang memanfaatkan laboratorium atau tidak melaksanakan praktikum baik di kelas maupun di luar kelas, padahal dengan praktikum dapat mengembangkan proses berpikir siswa dan memberikan pengalaman belajar siswa serta mengembangkan keterampilan dasar bekerja siswa secara nyata.

$$
\text { Berdasarkan kondisi yang }
$$

ditemukan di lapangan, maka perlu dilakukan analisis pelaksanaan praktikum dan pemanfaatan laboratorium dalam menunjang proses pembelajaran sehingga tujuan pembelajaran tercapai sesuai dengan kurikulum.

\section{Praktikum}

Praktikum berasal itu dari bahasa Perancis yaitu dari kata practique, dari bahasa Latin yaitu practic dan bahasa Yunani praktikos atau prattien/prassein yang berarti "mengerjakan". Kata praktikum secara harfiah berarti "aktif". Sedangkan dalam bahasa Inggris, praktikum bermakna sama dengan excersice atau exercice, yang secara harfiah berarti "tetap aktif/sibuk" yng bermakna sama dengan "latihan" atau "response".

Dari hasil penelitian Fekede Tuli (2009:38), "The findings indicated that the participants perceived practicum as an important tool of learning to teach because it promoted the development of teaching experience and prepared them for the real world of work. The analysis revealed that theory practice connection, competency and confidence development and socialization as a successful experience of the practicum program".

Terbukti bahwa praktikum dapat meningkatkan rasa kepemilikan siswa dalam pembelajaran mereka dan dapat meningkatkan motivasi mereka.

\section{Pentingnya Kegiatan Praktikum}

Ada empat alasan yang dikemukakan para pakar pendidikan IPA mengenai pentingnya kegiatan praktikum (Rustaman, 2005:136) yaitu:

\section{a. Praktikum membangkitkan motivasi belajar IPA}

Motivasi memengaruhi belajar siswa yang termotivasi untuk belajar lebih mendalam. Menurut faham psikologi humanism dalam diri individu terdapat dorongan untuk memeroleh pengetahuan dan kemampuan (Mahiruddin, 2008:6). Praktikum memberi kesempatan kepada siswa untuk memenuhi dorongan rasa ingin tahu dan ingin bisa. Prinsip ini sangat menunjang kegiatan praktikum yang di dalamnya siswa menemukan pengetahuan melalui eksplorasinya terhadap alam.

\section{b. Praktikum mengembangkan keterampilan dasar bereksperimen \\ Dalam rangka mengembangkan} kemampuan eksperimen pada diri siswa melalui kegiatan praktikum, perlu dilatihkan kemampuan observasi secara cermat, agar mereka mampu melihat kesamaan dan perbedaan serta menangkap sesuatu yang esensial dari fenomena yang diamatinya.

\section{c. Praktikum menjadi wahana belajar pendekatan ilmiah}

Banyak pakar pendidikan IPA meyakini bahwa tidak ada cara terbaik agar siswa belajar pendekatan ilmiah kecuali menjadikan mereka sebagai scientist. Praktikum menunjang materi pelajaran

Praktikum memberi kesempatan bagi siswa untuk membuktikan teori, menemukan teori atau mengelusidasi teori dari kegiatan-kegiatan tersebut maka pemahaman siswa terhadap suatu pelajaran telah merasionalisasi fenomena ini. Keyakinan akan kontribusi praktikum bagi pemahaman materi pelajaran.

Menurut Mahiruddin (2008:4) praktikum dapat mengembangkan keterampilan dasar melakukan eksperimen (1), mengembangkan kemampuan 
memecahkan masalah dengan pendekatan ilmiah (2), meningkatkan pemahaman mengenai materi pelajaran (3).

\section{(1) Praktikum untuk mengembangkan keterampilan dasar. \\ Keterampilan hanya dapat} dikembangkan melalui latihan. Oleh karena itu mesti ada kegiatan praktikum yang lebih menekankan pengembangan keterampilan menggunakan alat, observasi, mengukur dan keterampilan lainnya.

\section{(2) Praktikum dalam kemampuan memecahkan masalah}

Melalui praktikum, siswa memeroleh pengalaman mengidentifikasi masalah nyata yang dirasakannya serta merumuskannya secara operasional, merancang cara terbaik untuk memecahkan masalahnya dan mengimplementasikannya dalam laboratorium serta menganalisis dan mengevaluasi hasilnya.

\section{Praktikum untuk peningkatan pemahaman materi pelajaran}

Perlu adanya kontribusi kegiatan praktikum pada peningkatan pemahaman serta perluasan wawasan pengetahuan (fakta, konsep, prinsip, teori) siswa. Kontribusi ini hanya dapat terwujud jika ada kegiatan praktikum yang bersifat memberikan pengalaman bagi siswa untuk mengindera fenomena alam dengan segenap inderanya (peraba, penglihatan, pengecap, pendengar dan penciuman).

\section{Pengertian Laboratorium}

Laboratorium berasal dari kata "laboratory" yang memiliki pengertian yaitu: (1) tempat yang dilengkapi peralatan untuk melangsungkan eksperimen di dalam sains atau melakukan pengujian dan analisis (is a place equipped for experimental study in a science or for testing and analysis , (2) bangunan atau ruangan yang dilengkapi peralatan untuk melangsungkan penelitian ilmiah ataupun praktik pembelajaran bidang sains (a building or room equipped for conducting scientific research or for teaching practical science), (3) tempat memproduksi bahan kimia atau obat (a place where chemicals or medicines are manufactured), (4) tempat kerja untuk melangsungkan penelitian ilmiah ( a workplace for the conduct of scientific research), (5) ruang kerja seorang ilmuwan dan tempat menjalankan eksperimen bidang studi sains (kimia, fisika, biologi, $\mathrm{dsb}$ ). (the workplace a saintist also a place devoted to experiments in any branch of natural science, as chemistry, physics, biology etc. ).

\section{Fungsi Laboratorium Biologi}

Secara umum, fungsi semua laboratorium adalah:

a. Sebagai tempat dilakukannya percobaan

Alat-alat laboratorium dan bahan-bahan praktikum tidak mungkin semuanya diletakkan dalam kelas, oleh karena itu percobaan dilakukan di dalam laboratorium.

b. Sebagai tempat penunjang kegiatan kelas

Dengan adanya kegiatan pembelajaran di laboratorium, siswa dapat mengamati gejala-gejala yang terjadi dalam percobaan secara langsung dan tidak hanya belajar menurut teori-teori yang ada.

c. Sebagai tempat display/pameran

Laboratorium juga dapat digunakan sebagai tempat pameran atau display dari hasil-hasil percobaan atau penelitian yang telah dilakukan, agar memberi gambaran lebih bagi siswa dan dapat memotivasi untuk penelitian atau percobaan yang lebih baik.

d. Sebagai tempat koleksi sejumlah spesies langka

Dengan adanya koleksi sejumlah spesies memudahkan siswa mengamati secara langsung spesies yang mungkin sulit untuk menemukannya.

e. Laboratorium dapat digunakan sebagai museum kecil (Indica, 2011:2).

Tujuan Pembelajaran di Laboratorium

Adapun tujuan pembelajaran di laboratorium bagi siswa adalah:

a. Teliti dalam pengamatan dan cermat dalam pencatatan pada saat pengamatan

b. Mampu menafsirkan hasil percobaan untuk memeroleh penemuan dan dapat memecahkan masalah

c. Mampu merencanakan dan melaksanakan percobaan

d. Terampil menggunakan alat-alat laboratorium 
e. Menumbuhkan sikap positif terhadap kegiatan praktikum

\section{Metode Penelitian}

Penelitian dilaksanakan di SMP Negeri Se-Kecamatan Medan Kota dari Mei 2012 sampai Juni 2012.
Populasi yang dijadikan objek penelitian yaitu seluruh guru yang mengajar mata pelajaran biologi di Kelas VII dan seluruh siswa Kelas VII semester genap di SMP Negeri Se- Kecamatan Medan Kota yang dapat kita lihat pada Tabel 3.1.

Tabel 3.1. Keadaan populasi Jumlah Guru Biologi Kelas VII dan Siswa Kelas VII SMP Negeri Se-Kecamatan Medan Kota

\begin{tabular}{ccccc}
\hline \multicolumn{2}{c}{$\begin{array}{c}\text { Nama } \\
\text { Sekolah }\end{array}$} & Jlh Guru Biologi & $\begin{array}{c}\text { JLH } \\
\text { Siswa }\end{array}$ & Lokasi \\
\hline SMP & 3 & $\mathbf{2}$ & $\mathbf{4 0}$ & Jl. Pelajar No. 44 (Teladan) \\
SMP & 4 & $\mathbf{2}$ & $\mathbf{4 0}$ & Jl. Bahagia (Sidoarjo) \\
SMP 6 & $\mathbf{3}$ & $\mathbf{4 0}$ & Jl. Bahagia (Teladan Timur) \\
SMP & 8 & $\mathbf{2}$ & $\mathbf{4 0}$ & Jl. Jati III N0.118 (Teladan) \\
SMP 12 & $\mathbf{4}$ & $\mathbf{4 0}$ & Jl. Thamrin Pusat Pasar \\
\hline 5 Sekolah & $\mathbf{1 3}$ orang & $\mathbf{2 0 0}$ orang & Kec. Medan Kota \\
\hline
\end{tabular}

\section{Teknik Pengumpulan Data}

Teknik pengumpulan data dalam penelitian ini dapat dilakukan pada beberapa metode yaitu:

\section{a. Observasi}

Metode observasi pada penelitian ini menggunakan observasi terstruktur yaitu observasi yang dirancang secara sistematis tentang pengamatan, waktu dan tempat penelitian. Pengamatan dilakukan tentang pelaksanaan praktikum meliputi: keadaan sarana laboratorium biologi, ketersediaan kelengkapan alat dan bahan yang mendukung pelaksanaan praktikum biologi di Kelas VII semester genap SMP Negeri Se-Kecamatan Medan Kota. Melakukan observasi meliputi pengumpulan data: jumlah populasi siswa dan guru biologi SMP Negeri Se-Kecamatan Medan Kota dimana jumlah seluruh guru biologi dari ke 5 SMP Negeri tersebut adalah 13 orang dan jumlah seluruh siswa kelas VII adalah 200 orang. Hal yang diungkap melalui observasi yaitu:

1. Keadaan sarana laboratorium IPA Biologi Kelas VII semester genap di SMP Negeri Se-Kecamatan Medan Kota.

2. Permasalahan apa yang dihadapi dalam pelaksanaan praktikum IPA Biologi Kelas VII semester genap di
SMP Negeri Se-Kecamatan Medan Kota.

\section{b. Angket (Koesioner)}

Angket yang digunakan berupa angket tertutup yang disajikan dalam bentuk sedemikian rupa sehingga responden diminta untuk memilih salah satu jawaban yang sesuai dengan karakteristik dirinya dengan cara memberikan tanda checklist. Angket ini dibuat menurut Skala Likert yaitu salah satu teknik pengukuran sikap, pendapat dan persepsi seseorang. Angket ini diberikan kepada guru dan siswa.

\section{Hasil Penelitian \\ Frekuensi Pelaksanaan Praktikum}

Jumlah kegiatan praktikum biologi

SMP kelas VII selama semester genap sebanyak 12 kali praktikum. Secara umum, frekuensi pelaksanaan praktikum di SMP Negeri Se-Kecamatan Medan Kota ratarata $33,33 \%$ (4 kali praktikum), tergolong jarang.

Berdasarkan topik kegiatan praktikumnya, terdapat 2 topik yang dilaksanakan pada seluruh sekolah sampel yaitu pengamatan morfologi daun (Klasifikasi makhluk hidup), dan pengamatan terhadap ciri-ciri makhluk hidup yaitu $100 \%$. Urutan berikutnya pengamatan insekta misalnya: 
lalat, semut atau belalang (Keanekaragaman makhluk hidup), sebesar $80 \%$ dilaksanakan oleh 4 . sekolah kecuali SMP Negeri E. Praktikum pengamatan struktur bunga (Organisasi kehidupan) dilaksanakan 3 sekolah yaitu SMP Negeri A, SMP Negeri B dan SMP Negeri E, sebesar 60\%, pengamatan sel bawang (Mikroskop dan penggunaannya), pengamatan preparat batang, akar dan daun dikotil dan monokotil (Organisasi kehidupan) dilaksanakan 2 sekolah yaitu SMP Negeri A dan SMP Negeri $B$, pengamatan tumbuhan tingkat tinggi sebesar (Keanekaragaman makhluk hidup), dilaksanakan 2 sekolah yaitu SMP Negeri A dan SMP Negeri C, masing-masing sebesar $40 \%$. Sedangkan pengamatan terhadap overkulum pada insang ikan dalam perairan (Ekosistem) dilaksanakan SMP Negeri E, sebesar 20\%. Sedangkan pengamatan yang tidak pernah dilaksanakan oleh semua sekolah sampel adalah pengamatan sel pati pada umbi, pengamatan preparat pada awetan otot polos pada hewan dan pengamatan eutrofikasi pada enceng gondok serta pengamatan sel epitel (sel pada pipi) yaitu $0 \%$.

Frekuensi pelaksanaan praktikum persentase tertinggi 7 kali praktikum (58.33\%) pada SMP Negeri B, kemudian SMP Negeri A melaksanakan 6 kali praktikum (50\%), SMPN C dan SMP Negeri E masing-masing melaksanakan 4 kali praktikum (33,33\%), sedangkan SMPN D melaksanakan 3 kali praktikum (25\%). Maka apabila dirata-ratakan frekuensi pelaksanaan praktikum biologi di SMP Negeri Se-Kecamatan Medan Kota, sebesar 39,99\%, kategori jarang melaksanakan praktikum biologi (Gambar 4.1.).

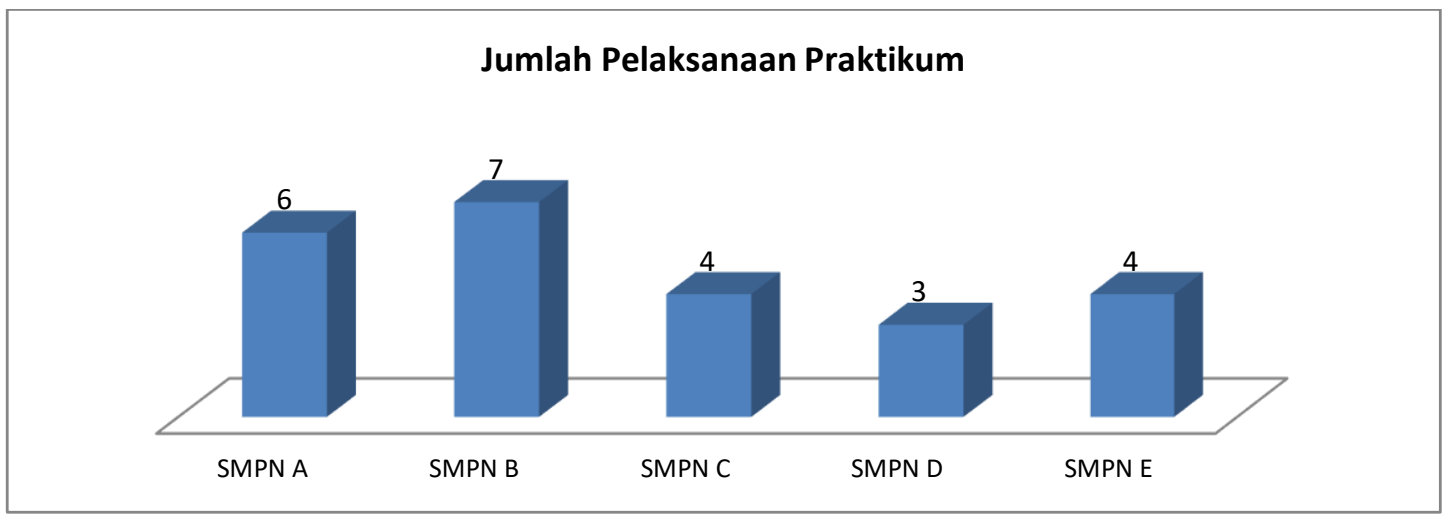

Gambar 1. Frekuensi Pelaksanaan Praktikum Di SMP Se-Kecamatan Medan Kota

Keadaan laboratorium biologi SMP
Negeri Se-Kecamatan Medan Kota.

Berdasarkan hasil penelitian bahwa keadaan laboratorium SMP Negeri SeKecamatan Medan Kota tergolong kurang memadai, rata-rata mencapai $40,01 \%$. Persentase tertinggi pada SMP Negeri $A$, mencapai 56,99\%, tergolong cukup memadai, dan terendah pada SMP Negeri D, mencapai $23,10 \%$, kategori kurang memadai. Keadaan laboratorium terdiri dari kondisi laboratorium, peralatan laboratorium dan perlengkapan laboratorium dengan kategori kurang baik, masing-masing persentasenya yaitu 39,61 $\%, 39,87 \%$ dan $40,57 \%$.

Kondisi laboratorium dengan persentase tertinggi pada SMP Negeri $B$, mencapai $54,16 \%$ dan terendah SMP Negeri D, mencapai 23,95\%, kategori kurang memadai. Pada peralatan laboratorium persentase tertinggi pada SMP Negeri A, tergolong memadai, mencapai $74,68 \%$ dan terendah pada SMP Negeri D, tergolong cukup memadai, mencapai $\quad 57,34 \%$. Sedangkan perlengkapan laboratorium, persentase tertinggi juga pada SMP Negeri A, mencapai $65,37 \%$ dan terendah pada SMP Negeri D, mencapai $20,83 \%$, kategori tidak

\section{Waktu pelaksanaan praktikum biologi SMPegerti Se-Kecamatan Medan Kota}

Secara umum waktu pelaksanaan praktikum pada sekolah sampel tergolong kurang mencukupi, rata-rata keadaannya mencapai $39,42 \%$, yang terdiri dari alokasi waktu praktikum dan praktikum di luar ruangan laboratorium, tergolong kurang 
mencukupi dengan persentase $40,49 \%$ dan $38,36 \%$.

Persentase tertinggi untuk alokasi waktu praktikum yaitu $54,68 \%$, pada SMP Negeri B, dan terendah pada SMP Negeri D, mencapai $24,21 \%$, kategori kurang mencukupi. Sedangkan praktikum di luar ruangan laboratorium persentase tertinggi juga SMP Negeri B, mencapai 50,93\%, kategori mencukupi dan terendah pada SMP Negeri D, mencapai $24,37 \%$, kategori kurang mencukupi.

\section{Persiapan dan Prosedur Pelaksanaan Praktikum Biologi}

Hasil penelitian menunjukkan bahwa persiapan dan prosedur pelaksanaan praktikum biologi di SMP Negeri SeKecamatan Medan Kota pada umumnya cukup baik dengan rata-rata 51,43\%, Persiapan dan prosedur pelaksanaan praktikum persentase tertinggi pada SMPN $B$, mencapai $63,32 \%$, tergolong baik dan terendah SMP Negeri D, mencapai $29,45 \%$, tergolong kurang baik.

Persiapan dan prosedur pelaksanaan praktikum terdiri dari cara pelaksanaan praktikum dengan rata-rata $46,40 \%$, kategori kurang baik, persiapan guru dalam pelaksanaan praktkum, jadwal pelaksanaan praktikum dan penuntun praktikum masingmasing mencapai 50,68\%, 55,58\% dan $53,07 \%$ dengan kategori cukup baik.

Cara pelaksanaan praktikum persentase tertinggi SMP Negeri B, mencapai 66,24\%, kategori baik dan terendah pada SMP Negeri D, mencapai $26,45 \%$, kategori kurang baik. Sedangkan pada persiapan guru dalam praktikum dengan persentase tertinggi pada SMP Negeri A, mencapai $62,96 \%$, kategori baik dan terendah pada SMP Negeri D, mencapai 29,68\%, kategori kurang baik. Untuk jadwal pelaksanaan praktikum dengan persentase tertinggi SMP Negeri B, mencapai 65,83\%, kategori baik dan terendah SMP Negeri D,mencapai 30,22\% kategori kurang baik. Sedangkan penuntun praktikum, persentase tertinggi SMP Negeri C, mencapai $74,37 \%$ dan terendah SMP Negeri D, mencapai $31,45 \%$, kategori kurang baik.

\section{Permasalahan dalam Pelaksanaan Praktikum Biologi di SMP Negeri Se- Kecamatan Medan Kota}

Secara umum permasalahan dalam pelaksanaan praktikum pada sekolah sampel tergolong sedikit, rata-rata keadaannya mencapai $47,56 \%$, yang terdiri dari kemampuan guru dalam pelaksanaan praktikum dengan rata-rata 40,87\%, tergolong kurang baik, laporan hasil praktikum mencapai $44,77 \%$, tergolong cukup baik dan ujian praktikum, rata-rata mencapai 57,05\%, tergolong cukup baik.

Kemampuan guru dalam pelaksanaan praktikum dengan persentase tertinggi SMP Negeri B, mencapai 54,12\%, kategori cukup mampu dan terendah pada SMP Negeri D, mencapai 27,37\%, kategori kurang mampu. Laporan hasil praktikum, persentase tertinggi juga pada SMPN B, mencapai 54,06\%, kategori cukup baik dan terendah pada SMP Negeri D, mencapai $29,21 \%$. Sedangkan ujian praktikum, persentase tertinggi pada SMP Negeri B, mencapai 66,56\%, kategori baik dan terendah pada SMP Negeri A, mencapai $44,68 \%$, kategori cukup baik.

\section{Observasi Keadaan Sarana dan Prasarana Laboratorium}

Berdasarkan hasil observasi yang dilakukan terhadap keadaan sarana dan prasarana laboratorium di SMP Negeri SeKecamatan Medan Kota, maka data yang diperoleh dapat disajikan pada Lampiran 4.

\section{PEMBAHASAN}

\section{Keadaan sarana dan prasarana Laboratorium \\ Laboratorium merupakan tempat} berlangsungnya kegiatan pembelajaran yang memerlukan peralatan khusus yang tidak mudah dihadirkan di ruang kelas. Kadarohman (2007:3) mengatakan: "ruang laboratorium merupakan tempat berlangsungnya proses pembelajaran". Proses pembelajaran di dalam ruang laboratorium dapat berupa peragaan dan demonstrasi, praktikum perorangan atau kelompok. Proses pembelajaran di ruang laboratorium menunut tempat yang lebih luas daripada proses pembelajaran klasikal di kelas biasa.

Secara umum dari hasil analisis data yang diperoleh di SMP Negeri SeKecamatan Medan Kota menunjukkan, 
bahwa keadaan sarana dan prasarana laboratorium tergolong kurang memadai dengan presentase $39 \%$. Hal ini terjadi karena ruangan laboratorium tidak hanya digunakan untuk belajar tetapi juga dimanfaatkan sebagai gudang, tempat belajar siswa dan tempat rapat guru-guru serta ruangan pertemuan OSIS di sekolah tersebut (Sudirman, 2008:96).

\section{Frekuensi Pelaksanaan Praktikum Biologi}

Jenis praktikum yang dilaksanakan oleh seluruh sekolah di SMP Negeri SeKecamatan Medan Kota adalah pengamatan morfologi daun (Klasifikasi makhluk hidup), dan pengamatan terhadap ciri-ciri makhluk hidup yaitu $100 \%$. Hal ini dikarenakan mudahnya mendapatkan bahan untuk praktikum sehingga para guru dapat melaksanakan praktikum pada ke dua topik ini.

Jenis praktikum yang tidak dilaksanakan seluruh sekolah sampel adalah pengamatan sel pati pada umbi, pengamatan preparat pada awetan otot polos pada hewan dan pengamatan eutrofikasi pada enceng gondok serta pengamatan sel epitel (sel pada pipi) yaitu $0 \%$.

Tidak terlaksananya praktikum pengamatan eutrofikasi pada enceng gondok, ini disebabkan sukarnya mendapatkan bahan praktikum karena lokasi sekolah berada di daerah perkotaan dan kurangnya inisiatif guru untuk melaksanakan praktikum ini. Sedangkan jenis praktikum tentang pengamatan sel pati pada umbi, pengamatan preparat pada awetan otot polos pada hewan serta pengamatan sel epitel (sel pada pipi) juga tidak dilaksanakan ini disebabkan karena pengambilan sampelnya terlalu rumit, guru merasa direpotkan karena ketersediaan air bersih di ruangan laboratoriumpun kurang lancar sehingga airnya harus diangkat dari toilet, hal ini akan mengurangi waktu praktikum.

Faktor lain yang berpengaruh terhadap keberhasilan pembelajaran yaitu faktor guru, faktor siswa, lingkungan belajar, penguasaan materi, penguasaan metode mengajar dan teknik mengajar oleh guru dan kepribadian guru sendiri. Lingkungan belajar akan tercipta dari interaksi antara guru dan siswa di dalam lingkungaan fisik pendukungnya.
Peran guru sangat besar dalam kegiatan belajar mengajar. Kemampuan dan metode guru dalam memberikan materi pelajaran sangat memengaruhi keberhasilan siswa dalam memahami pelajaran. Menururt Tuli (2009:44) menyatakan pengalaman mengajar adalah sarana utama guru untuk mengajar.

\section{Waktu pelaksanaan praktikum biologi}

Pelaksanaan praktikum di SMP Negeri Se-Kecamatan Medan Kota kategori kurang mencukupi, penjadwalan praktikum masih dilakukan oleh guru biologi itu sendiri. Hal ini sesuai dengan data yang diperoleh bahwa waktu yang tersedia dalam pelaksanaan praktikum kurang mencukupi dengan persentase $34.84 \%$, hal ini disebabkan belum adanya petugas khusus laboratorium yang bertugas menyiapkan dan membereskan alat-alat pada waktu guru melakukan proses belajar mengajar dengan metode praktikum sehingga guru tidak mempunyai cukup waktu untuk mempersiapkan kegiatan percobaan.

Penyebab lain adalah guru harus mencari tambahan mengajar di sekolah lain akhirnya guru mengajarkan mata pelajaran dengan ceramah saja yang penting materi selesai tanpa melihat fungsi dan tujuan pembelajaran kalaupun guru memersiapkan di luar jam sekolah, tidak ada tambahan sebagai kelebihan jam mengajar (upi.eduopeatoruploadd_ipa:7).

Dari temuan di lapangan, praktikum yang dilaksanakan di luar jam sekolah lebih tidak memungkinkan lagi karena ruangan laboratorium dipakai untuk ruangan belajar untuk tambahan kelas sore dan guru yang mengajar di kelas pagi juga mengajar di kelas sore.

\section{Persiapan dan Prosedur Pelaksanaan Praktikum}

Secara umum dari hasil penelitian menunjukkan bahwa persiapan dan prosedur pelaksanaan praktikum tergolong cukup baik $(54,40 \%)$.

Dalam hal ini, guru sangat berperan dalam menyiapkan alat dan bahan sebelum pelaksanaan praktikum. Sebelum praktikum terlebih dahulu guru membagi siswa menjadi beberapa kelompok, memberikan penjelasan tentang kegiatan yang akan dilaksanakan dan menyampaikan tujuan dari setiap praktikum yang akan 
dilaksanakan. Namun ada ditemukan persentase persiapan dan prosedur pelaksanaan praktikum $34,87 \%$ dan $45,95 \%$. Hal ini disebabkan kurangnya kemampuan guru dalam mengelola dan menyiasati proses pembelajaran di laboratorium sehingga siswa tidak merasa tertarik dan tidak adanya petugas khusus laboratorium yang membantu memersiapkan segala sesuatunya untuk keperluan praktikum sehingga pelaksanaan praktikum tidak berjalan sesuai dengan yang direncanakan.

Jadwal praktikum di SMP Negeri SeKecamatan Medan Kota umumnya dibuat oleh guru biologi itu sendiri dan dibuat sebelum praktikum dimulai. Namun di SMPN E jadwal praktikum sudah ada diawal semester.

\section{Permasalahan dalam Pelaksanaan Praktikum}

Permasalahan dalam pelaksanaan praktikum di SMP Negeri Se-Kecamatan Medan Kota tergolong sedikit dengan persentase $63,43 \%$. Walaupun demikian pada dua sekolah terdapat persentase $57,13 \%$ dan $45 \%$. Ini terjadi karena pada sekolah tersebut keadaan sarana dan prasarana sebagai modal utama dalam pelaksanaan praktikum kurang memadai, sehingga akan menghambat tercapainya tujuan pembelajaran yang diharapkan.

Kendala lain adalah perlu adanya perhatian Dinas Pendidikan Kota Medan dalam menyediakan ruang dan perlengkapan laboratorium yang standar karena keberadaan laboratorium yang memadai sangat penting sebagai sarana penunjang proses pembelajaran, kenyataannya menunjukkan masih banyak sekolah yang tidak memiliki sarana laboratorium yang lengkap. Hal tersebut disebabkan oleh mahalnya alat sarana dan prasarana pendidikan, terlebih untuk harga peralatan laboratorium IPA merupakan faktor yang paling banyak dikeluhkan oleh pihak sekolah (Mahiruddin, 2008:3).

Dari hasil analisis data, ujian praktikum diperoleh persentase 69,49\%, hal ini disebabkan karena praktikum yang dilaksanakan kurang maksimal sehingga siswa kurang memahami apa yang dipraktikumkan dan akhirnya apabila dilakukan tes mereka kurang bisa menjawab segala pertanyaan yang ada. Sebagai contoh, penelitian telah menunjukkan bahwa guru sendiri tidak menganggap pentingnya praktik laboratorium dan biasanya guru memberi alasan untuk menghindari agar tidak melakukan praktikum (Abimbola, 1994:95).

Guru yang tidak dapat melakukan praktikum di laboratorium sebaiknya dapat merekam video tentang percobaan, tape untuk demonstrasi yang kemudian menunjukkannya kepada siswa pada saat praktikum, sekolah menengah modern saat ini cenderung menikmati menonton rekaman video daripada melakukan praktikum di laboratorium.

\section{Observasi Keadaan Sarana Laboratorium}

Laboratorium adalah suatu tempat dimana percobaan dan penyelidikan dilakukan. Tempat ini dapat merupakan ruangan tertutup, kamar atau ruangan terbuka misalnya kebun, taman, kolam bahkan hutan. Laboratorium berfungsi sebagai tempat kegiatan pembelajaran secara praktik dan laboratorium IPA khususnya memiliki peran yang teramat penting untuk mengembangkan dan membiasakan siswa berpola pikir discovery dan inkuiri. Dalam memeroleh struktur dan prinsip gejala dapat melalui percobaan, penyelidikan, memakai prosedur yang jelas urutan dan langkah-langkahnya sehingga dapat dilacak kembali nilai kebenaran struktur atau prinsip suatu gejala yang telah mereka peroleh. Peranan laboratorium IPA di sekolah diharapkan dapat menumbuhkembangkan siswa untuk berpikir secara ilmiah yaitu berdasarkan fakta yang ada.

Umumnya SMP Negeri Se-

Kecamatan Medan Kota sudah memiliki laboratorium IPA, namun laboratorium biologinya masih bergabung dengan laboratorium kimia dan fisika. Akan tetapi ada 1 sekolah yang sudah memiliki laboratorium khusus biologi yaitu SMP Negeri B dan kelengkapan alat laboratoriumnya ada 8 jenis belum tersedia, sedangkan untuk ukuran ruangan laboratoriumnya sudah memenuhi standar $90 \mathrm{~m}^{2}$, mempunyai ventilasi yang cukup.

Pada SMP Negeri E, ruangan laboratoriumnya sudah memenuhi standar namun kelengkapan alat dan bahannya 13 jenis belum tersedia. Pada SMP Negeri C keadaan ruang laboratoriumnya sangat sempit untuk menampung 40 orang siswa, begitu juga alat dan bahan laboratoriumnya 
35 jenis belum tersedia. Sedangkan SMP Negeri D, keadaan ruangannya begitu sempit. Jarak atap dan lantainya rendah sehingga sangat panas dan pengap, alat dan bahan laboratoriumnya hanya 18 jenis yang tersedia.

Berdasarkan hasil observasi, kendala utama dalam pelaksanaan praktikum biologi adalah minimnya jumlah mikroskop dan perlengkapan laboratorium lainnya belum tersedia sehingga praktikum jarang dilaksanakan, apalagi pada materi penggunaan mikroskop hanya dilakukan di kelas dengan membawa beberapa mikroskop itupun hanya menunjukkan bagian-bagian dari mikroskopnya saja tanpa dapat melakukan pengamatan dengan mikroskop.

Adanya kelengkapan sarana pembelajaran seperti tersedianya laboratorium diharapkan dapat mendukung kelancaran proses belajar mengajar biologi. Menurut Rustaman \& Rustaman (2005:97) laboratorium merupakan salah satu sarana penunjang yang banyak digunakan dalam proses belajar mengajar biologi, sedang sarana pada pembelajaran biologi dapat diartikan sebagai beberapa hal seperti berikut: a) sebagai unsur pencapaian tujuan, artinya sarana bukan semata-mata sebagai alat bantu atau pelengkap, melainkan bersama-sama dengan materi dan metode berperan dalam proses kegiatan belajar mengajar, agar tujuan pembelajaran tercapai sesuai dengan yang telah dirumuskan, b) sebagai pengembang kemampuan, terutama alat-alat yang dapat dimanipulasi atau dirakit atau dimodifikasi atau media yang sengaja direncanakan untuk meningkatkan kemampuan tertentu, c) sebagai katalisator dalam pemahamn materi, misalnya melalui alat yang diperagakan, perbuatan, pengalaman langsung, dan d) sebagai pembawa informasi, terutama dalam bentuk media misalnya gambar, radio, televise, film, dan slide film.

\section{KESIMPULAN}

Berdasarkan hasil deskripsi data dan pembahasan hasil penelitian, maka disimpulkan sebagai berikut:

1. Keadaan sarana laboratorium biologi di SMP Negeri Se-Kecamatan Medan Kota tergolong kurang memadai dengan rata-rata $39 \%$ masih belum memenuhi standarisasi yang telah ditentukan Peraturan Menteri Pendidikan Nasional RI No. 24 Tahun 2007 karena kondisi laboratoriumnya tidak terawat, ruangannya sempit dan pengap karena kurang tersedianya ventilasi udara.

2. Frekuensi pelaksanaan praktikum biologi kelas VII pada semester genap di SMP Negeri Se-Kecamatan Medan Kota jarang dilaksanakan dengan ratarata 39,99 \%. Seharusnya praktikum dilaksanakan sebanyak 12 jenis praktikum akan tetapi frekuensi praktikum paling tinggi 7 kali praktikum $(58,33 \%)$ dan terendah, 3 kali praktikum (25\%).

3. Permasalahan dalam pelaksanaan praktikum biologi semester genap Kelas VII di SMP Negeri SeKecamatan Medan Kota tergolong cukup banyak yaitu 52,51\%. Hal ini disebabkan kurang tersedianya kelengkapan sarana dan prasarana laboratorium, rendahnya kemampuan guru dalam mengelola dan melaksanakan praktikum. Disamping itu permasalahan lain adalah tidak adanya jadwal pelaksanaan praktikum serta belum tersedianya buku penuntun khusus praktikum yang selama ini hanya merupakan buku pegangan guru.

\section{DAFTAR PUSTAKA}

Abimbola, O, I. (1994). A critical appraisal of the role of laboratory practical work in science teaching in Nigeria. Journal of Curriculum and Instruction, 4 (1\&2), 59-65. (A publication of the Department of Curriculum Studies and Educational Technology, University of Ilorin, Ilorin).

Adisendjaja, Y. H., \& Roomlah, O. 2007. Identifikasi Kesalahan dan Miskonsepsi Buku teks Biologi SMU. Makalah disajikan dalam Seminar Nasional Pendidikan Biologi dan Biologi, Jurusan Pendidikan Biologi FMIPA, Universitas Pendidikan Indonesia, 25-26 Mei.

Arikunto, S. 2002. Prosedur Penelitian Suatu Pendekatan Praktek Edisi Revisi V. Penerbit Rineka Cipta.

Anonim. 2007. Peraturan Mendiknas RI, Nomor 24, Tahun 2007, tentang Standar Sarana dan Prasarana untuk Sekolah Dasar/Madrasah Ibtidaiyah (SD/MII), 
Sekolah Menengah Pertamal Madrasah Tsanawiyah (SMP/MTs) dan Sekolah Menengah Atas (SMA/MA) Pendidikan Umum.

Ajaja, OP. Evaluation of Science Teaching in Secondary Schools in Delta State 2 Teaching of the Sciences Kamla-Raj 2009 Int J Edu Sci, 1(2): 119-129 (2009) Department of Science Education, Delta State University, Abraka, Nigeria.

Akonbobola Olufunminiyi Akinyemi and Afolabi Folashade. Analysis of Science Process Skills in West African Senior Secondary School Certificate Physics Practical Examinations in Nigeria. Department of Science Education, Faculty of Education, University of Uyo, Uyo, Akwa Ibom State, Nigeria 2Department of Teacher Education, Faculty of Education, University of Ibadan, Ibadan, Oyo State, Nigeria. American-Eurasian Journal of Scientific Research 5 (4): 234-240, 2010 ISSN 18186785@ IDOSI Publications, 2010.

Arti dan Tujuan Praktikum. Diposkan oleh IdBlog.WEB.ID on 24/01/10 / Label: Pendidikan. diakses Januari 2012.

Bates, G.C. 1982. Pentingnya Laboratorium dalam IImu Sekolah. Jakarta.

Dahar, R.W. 1986. Interaksi Belajar Mengajar IPA. Jakarta UT.

Dahar, R.W. 1989. Teori-teori Belajar. Bandung: Gelora Aksara Pratama.

Depdiknas. 2004. Pedoman Khusus Pengembangan Silabus Berbasis Kompetensi SMP Mata Pelajaran IImu Pengetahuan Alam. Jakarta Depdiknas.

Depdikbud. 1993. Buku Katalog Alat Laboratorium IPA untuk SMP dan SMA. Jakarta: Dikmenum.

Dillon, J. A Review of the Research on Practical Work in School Science. March,

Gabel, D.L. 1994. Handbook of Research on Science Teaching and Learning New York:McMillan Publishing Company.

Gultom, H. 2011. Analisis Pemanfaatan Laboratorium dalam Pembelajaran Biologi di SMA Negeri Se-Kota Medan. Program Pascasarjana Unimed.

Gunawan, J. 1985. Komunikasi dalam Organisasi. Yogyakarta. Andi offsets.

Heru, W. 2010.2 Jenis-Jenis Praktikum. Diposkan oleh IdBlog. WEB.ID on 23/01/10.

Ibrahim, Z. 2011. Pengertian Laboratorium IPA. FKIP Unsam Langsa.
John Basey; Loren Sackett \& Natalie Robinson. Optimal Science Lab Design: Impacts of Various Components of Lab Design on Students' Attitudes Toward Lab. University of Colorado at Boulder. Boulder, Colorado, USA. International Journal for the Scholarship of Teaching and Learning. Vol. 2, No. 1 (January 2008). ISSN 1931-4744 (C) Georgia Southern University. http://www.georgiasouthern.edu/ijsotl

Laboratorium Research. Dipost Atok. April 2008. diakses Februari 2012.

Mahiruddin. 2008. Pengaruh Fasilitas Dan Kompetensi Pengelola Terhadap Efektifitas Manajemen Laboratorium IPA SMP Di Kabupaten Konawe. Facilities, Manager's Competencies, Science Laboratory, and Management Effectiveness). 